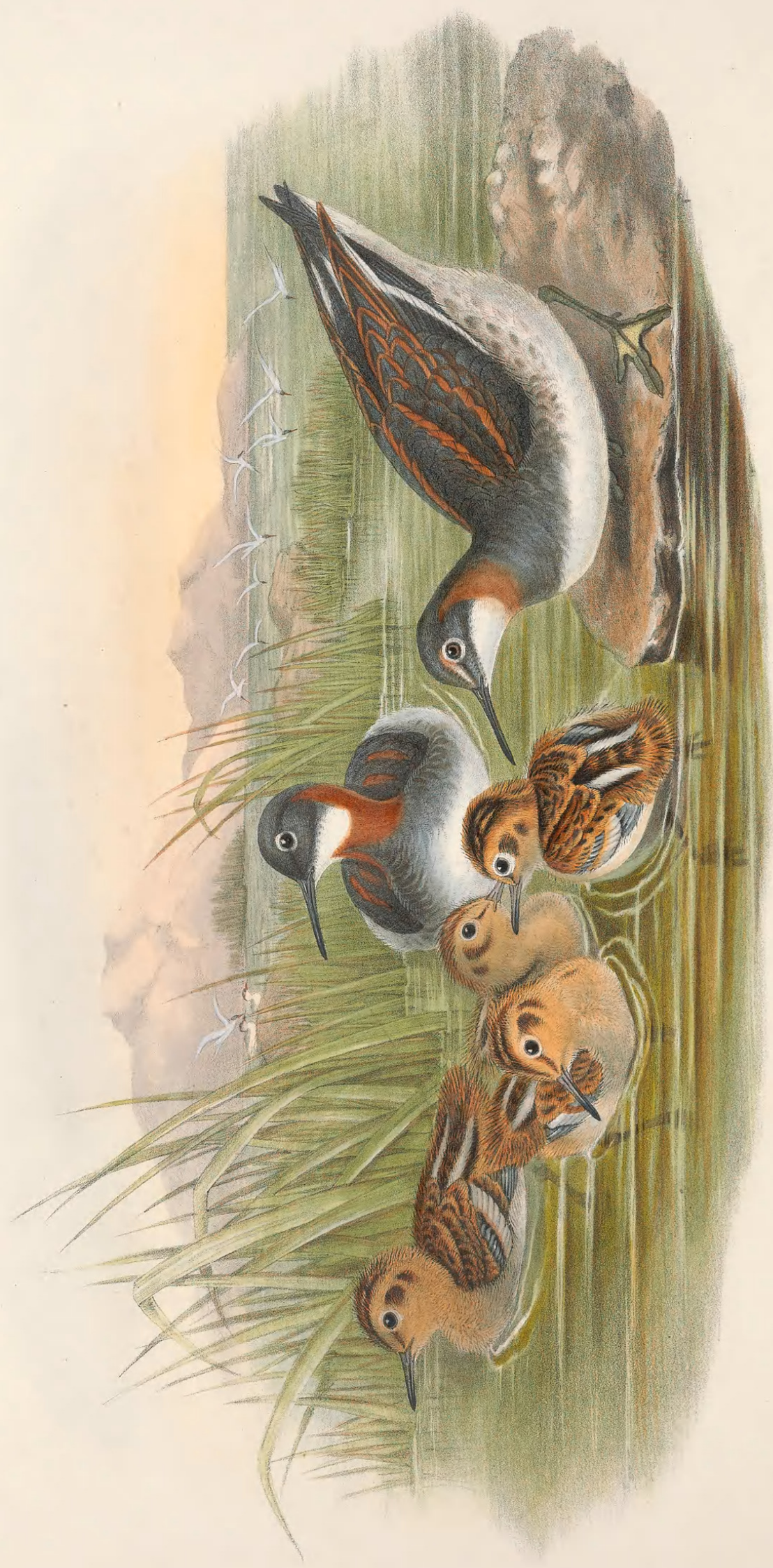




\section{LOBIPES HYPERBOREUS.}

\section{Red-necked Phalarope.}

Tringa lobata (pt.), Linn. Faun. Suec., p. 64.

- hyperborea, Linn. Syst. Nat., tom. i. p. 249.

fusca, Gmel. edit. Linn. Syst. Nat., tom. i. p. 675.

Phalaropus hyperboreus et fuscus, Lath. Ind. Orn., vol. ii. p. 775.

cinerascens et ruficollis, Pall. Zoog. Ross.-Asiat., tom. ii. p. 203.

angustirostris, Naum. Vög. Deutschl., 1836, tom. viii. p. 240, tab. 205

cinereus, Briss. Orn., tom. vi. p. 15.

Williamsii, Simm. in Linn. Trans., vol. viii. p. 264.

Lobipes hyperboreus, Cuv. Règ. Anim., 1829, tom. i. p. 532.

WHEN Bullock visited the Orkneys in 1813, and Mr. Salmon in 1831, this species was an abundant summer resident on those islands : but at this period (1866) it probably no longer resorts there; for Mr. J. H. Dunn writes, "The bird has been extirpated in Orkney by collectors and the improvement of agriculture." I am sure that there is no one of my readers but will share with me in regretting the expulsion of so beautiful and interesting a creature from the British Islands. Is there no living proprietor in Orkney that will guard a morass from future interlopers and entice this species back again? If this were done, the laudable act, I am sure, would be rewarded by success. A little further north the bird is still abundant, and Iceland would satisfy the cravings of the egg-collector for the next century; if not, there are Greenland, Norway, and Lapland to fall back upon, for in those countries it still breeds in comparative safety.

It would be natural to suppose that a bird whose breeding-quarters are so near at hand would be plentiful in England during the autumn and winter months; yet this is not the case; for the Red-necked Phalarope is at this season less common than the Grey, whose country of reproduction is almost unknown, but which is, doubtless, in the far north. The range of this species is much greater than that of its ally, and I question if there be any part of the world too distant for its winter visits. I have seen specimens from California, Mexico, Guatemala, and the coast of Chili, and also from China and India.

In England it has been killed in many counties; and if it be not included in the work of Thompson on the 'Birds of Ireland,' it must be that the bird has not as yet attracted the notice of the ornithologists of that country, for assuredly it must now and then occur there. Writing to me respecting this bird, Mr. Bond says, "The first specimen I ever had was shot by a friend of mine in September 1842, near Southend, Essex, where he saw the Phalarope swimming on the water, like a little Duck, about a mile from land: not knowing what it was, he shot it, and kindly brought it to me; it is in the grey or winter plumage. I have also a very handsome male, in summer plumage, shot while running between the metals on the Great Eastern Railway, near the Stratford Station, early in June 1852." This is the nearest to London I have known of one being obtained. Mr. Stevenson informs me that "This species, always considered much more rare on the Norfolk coast than the Grey Phalarope, has of late years become extremely so; indeed I know of but four specimens killed in this country during the last fifteen years. It is, however, very remarkable that a bird, generally so scarce and irregular in its visits, should have appeared on the same parts of our coast in the three successive autumns of 1846,1847 , and 1848."

The following interesting account of this elegant little species is from the pen of the late Mr. St. John ; and its perusal will, I am sure, impress my readers with a desire to see, at least once in their lives, the bird in a state of nature, and induce them to excuse me for reprinting it in the present work :-

"The Red-necked Phalarope is certainly the most beautiful little wader of my acquaintance. There were a pair of them, male and female, feeding near the loch, in a little pool which was covered with weeds of different kinds. Nothing could be more graceful than the movements of these two little birds as they swam about in search of insects, \&c. Sometimes they ran lightly on the broad leaves of the Water-lily, which served them for a raft, and entirely kept them out of the water. Though not exactly web-footed, the Phalarope swims with the greatest ease. The attachinent of these two birds to each other seemed very great; whenever in their search for food they wandered so far apart as to be hidden by the intervening weeds, the male bird stopped feeding suddenly and, looking round, uttered a low and musical call of inquiry, which was immediately answered by the female in a different note, but perfectly expressive of her answer, which one might suppose to be to the purport that she was at hand and quite safe; on hearing her the male immediately recommenced feeding, but at the same time making his way towards her; she also flew to meet him: they then joined company for a moment or two, and after a few little notes of endear- 
ment, turned off again in different directions. This scene was repeated a dozen times while I was watching them. They seemed to have not the slightest fear of me; for frequently they came within a yard of where I was sitting, and after looking up they continued catching the small water-insects, \&c., on the weeds without minding my presence in the least.

"After having apparently exhausted the food in one pool, on a signal from the male, they suddenly both took wing, and flew away to a fresh feeding-place two or three hundred yards off, where we afterwards found them. Though we could not discover the nest, I have no doubt that they had eggs very near the spot where we saw them. Indeed on dissecting the female we found two eggs in her, nearly full-sized; so that probably she had already deposited the other two, which would have made her number complete. I find no account of this bird breeding on the mainland of Scotland."

Mr. Newton states, in his Notes on the Ornithology of Iceland, that this species is "very common on all the ponds and lakes of the island. Arrives late in May, and at once begins the duties of nidification. On one occasion, in the month of June, I saw a flock of at least a hundred sitting on the surf between the breaking waves and the shore."

"This beautiful little species," says Mr. Salmon, in his account of the birds seen by him in Orkney, published in the 'Magazine of Natural History,' " appeared to be very tame. Although we shot two pairs, those that were swimming about did not take the least notice of the report of the gun : and they seemed to be much attached to each other; for when one of them flew to a short distance, the other directly followed ; and while I held a wounded female in my hand, its mate came and fluttered before my face. We were much gratified in watching the motions of these elegant little creatures as they kept swimming about and were for ever dipping their bills into the water; and so intent were they in their occupation, that they did not take the least notice of me, although within a few yards of them. After some little difficulty, we were fortunate in finding their nests, which were placed in small tufts of grass growing close to the edge of the loch; they were formed of dried grass, and were about the size of that of a Titlark, but much deeper. They had but just commenced laying (June 13); for we found only one or two eggs in each nest, but were informed they always lay four."

Mr. Dunn in his 'Ornithologist's Guide to Orkney and Shetland' says, "I have never seen this bird in Shetland. I got several in Orkney, but it is not plentiful. The places where I procured their eggs, and found the birds most numerous, are a small sheet of water about three or four miles from the lighthouse of Sanda, a lake near Nunse Castle, in Westra, and at Sandwich, near Stromness."

Mr. Wolley, writing to Mr. Hewitson, says, "The few nests I have seen have been in little grassy islets in shallow boggy lakes or ponds, in moss or in a tuft of grass close to the water's edge or, sometimes, a few feet away. In the Faroe Islands it is found in a cluster of ponds, in one of the largest of them. In Lapland it breeds only far up the country, and sparingly. The bird is extremely tame, swimming about my indiarubber boat so near that I could almost catch it in my hand; I have seen it even, when far from its nest, struck at many times with an oar before it flew away." Bullock informed Montagu that the Red-necked Phalarope "swims with the greatest ease, and, when on the water, carries its head close to the back, in the manner of a Teal, and looks like a beautiful miniature of a Duck."

The egg is one inch and an eighth long by seven eighths of an inch broad, and is of a buffy stone-colour, blotched all over with blackish brown and pale purple.

Modern ornithologists consider the structural differences which occur in the Phalaropes of sufficient importance to divide them into two genera, - the present bird, with its narrow bill, being made the type of Lobipes, and having associated with it the fine $L$. Wilsoni of America, while that of Phalaropus has been retained for the preceding broad and flat-billed species. No others have yet been discovered, and I scarcely think it likely that the group will ever be added to.

The sexes of the present bird differ in the same way as the grey species; - the female being the largest, and by far the most finely coloured during the period of spring and summer. In winter they both become white beneath and mottled brownish black and grey above; the two species are then somewhat similar in colour; but the difference in the form of the bill will always distinguish one from the other.

The Plate represents a male, a female, and four young birds, of the size of life. The figures of the latter were drawn from two specimens taken in Orkney, and which are now in the Ashmolean Museum at Oxford. 


\section{$2 \mathrm{BHL}$ Biodiversity Heritage Library}

Gould, John. 1873. "Red-necked Phalarope, Lobipes hyperboreus [PI. 83]." The birds of Great Britain 4, -. https://doi.org/10.5962/p.324037.

View This Item Online: https://www.biodiversitylibrary.org/item/221609

DOI: https://doi.org/10.5962/p.324037

Permalink: https://www.biodiversitylibrary.org/partpdf/324037

\section{Holding Institution}

Smithsonian Libraries

\section{Sponsored by}

Biodiversity Heritage Library

\section{Copyright \& Reuse}

Copyright Status: Public domain. The BHL considers that this work is no longer under copyright protection.

This document was created from content at the Biodiversity Heritage Library, the world's largest open access digital library for biodiversity literature and archives. Visit BHL at https://www.biodiversitylibrary.org. 